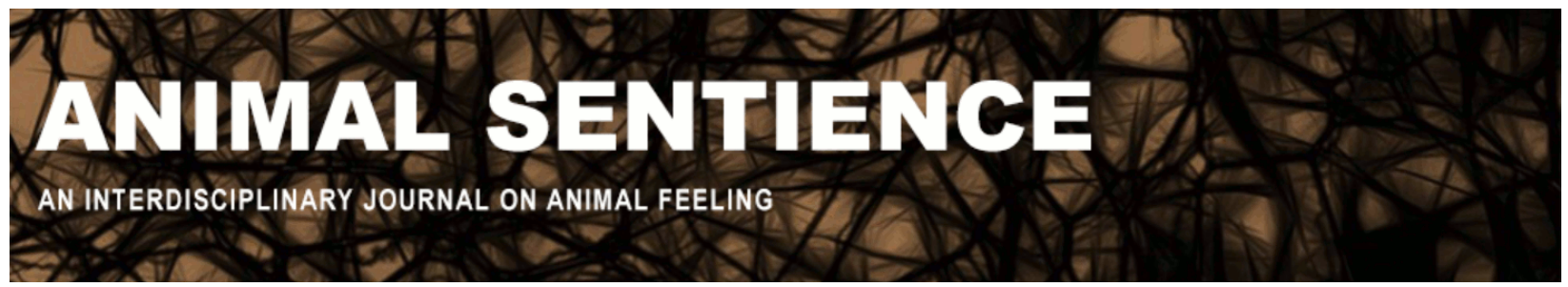

Zangwill, Nick (2021) Why do Chapman \& Huffman think humans are not different?. Animal Sentience 23(53)

DOI: $10.51291 / 2377-7478.1686$

Date of submission: 2021-11-14

Date of acceptance: 2021-11-14 (c) $\underset{\mathrm{EY}}{\mathrm{C}}$ 


\title{
Why do Chapman \& Huffman think humans are not different?
}

Commentary on Chapman \& Huffman on Human Difference

\author{
Nick Zangwill \\ University College London \& University of Lincoln
}

\begin{abstract}
This commentary discusses various shortcomings in Chapman \& Huffman's (2018) denial of differences between human beings and animals and the ethical consequences they think turn on this. Rationality is proposed as a candidate for such a difference, one that also has acceptable ethical consequences.
\end{abstract}

\begin{abstract}
Nick Zangwill, Honorary Research Fellow, University College London and Visiting Professor, University of Lincoln, works in moral philosophy, aesthetics, metaphysics, epistemology and philosophy of mind. Website
\end{abstract}

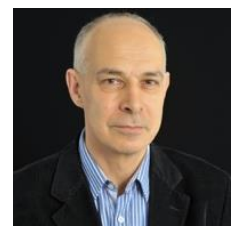

Chapman \& Huffman (2018) (C\&H) ask why we want to think humans are different from other animals. This looks like a psychological or sociological question. C\&H's answer is that human beings want to think they are different because they want to exploit and be cruel to non-human animals (henceforth simply 'animals'). This hypothesis is difficult to evaluate because C\&H provide no evidence to support it. No rival hypotheses are considered. One rival hypothesis is the simple one that people just think it is true that there are significant differences - the belief might not be motivated as C\&H suppose; and people might or might not also think that their view has the consequences that $\mathrm{C} \& \mathrm{H}$ fear for our treatment of animals.

C\&H believe that there are no characteristics that are unique to human beings, and C\&H sometimes add (as a matter of course) that such a unique factor would make human beings superior to the other animals. To this end they criticize some very old and implausible ways of distinguishing between humans and animals (Carlyle 1833; Osler 1891). But this is not a good argument. There have been other ideas since that time, such as the appeal to rationality and reason. One such account has been advanced by Christine Korgaard (for example Korsgaard 2006, Korgaard 2018a, Korsgaard 2018b), an idea to which I will return. What is most surprising, however, is that $\mathrm{C} \& \mathrm{H}$ also seem to accept that if there were morally significant human/animal differences, then they would justify humans mistreating animals. Why on earth believe that? We could surely recognize significant differences and think that humans and animals differ in respect of rights, obligations or duties because of the differences between them, but not in the way that C\&H fear. For example: to recognize certain differences between adults and children, or between men and women need not be to justify exploitative relations. Often it is quite the opposite. For example, we think that the very vulnerability of children places extra moral burdens on adults to care for them; and some countries have tax exemptions on women's sanitary products.

$\mathrm{C} \& \mathrm{H}$ seem to care a great deal about animals and about the environment. But to care for something you have to understand it. In the case of animals, this means understanding both what 
human beings share with animals and how human beings differ from them. Anything else only sentimentalises our relations with the animal kingdom and the environment-and ultimately harms both.

One not implausible thought is that human beings and animals share sentience (consciousness) while differing in rational capacity or purpose. As Korsgaard emphasized, rational capacity means something like a capacity to self-ascribe normative concepts and change one's mind as a consequence of that. (This is more than mere metacognition.) She calls this 'normative self-government'. This capacity differs greatly from sentience. It is obvious that emphasizing the rationality of human beings does not at all imply that the sentience of humans and animals does not matter. If an animal is sentient, then cruelty to it is wrong, whether it is human or not. But a difference in rational capacity means, for example, that only humans should be provided with an academic education or vote when a certain age, and so on. The difference in rationality yields moral differences, even though the similarity in sentience yields moral similarities.

$\mathrm{C} \& \mathrm{H}$ write as if any assertion of human uniqueness flies in the face of Darwin. But evolution results in many traits that distinguish between species, as quite a few of the commentators on C\&H's paper point out. So, why not also the human species? In particular, our rational capacities might be unique characteristics of human beings, and there is some evidence that it is. Now, it is true that Human rational capacities probably have primate evolutionary origins (Santos \& Rosati 2015), but that hardly shows that these capacities are not now unique to human beings.

Note that rationality conceived as normative self-government is different from intelligence, where "intelligence" means the ability to adapt behaviour in the light of information about the world (Nissani 2006, Beckers \& De Houwer 2016). Many species, including those that humans eat, exhibit considerable intelligence (Marino \& Allen 2017, Marino \& Merskin 2019). But intelligence does not imply the self-application of normative concepts in metacognition and subsequent changes in mindset, which is characteristic of human reasoning.

Against this, it might be argued that possessing normative concepts is not unique to human beings. It is true that there is evidence that some species have something that is not far from our human concept of justice (Brosnan and De Waal 2003). There are the monkeys who famously object to unequal reward for equal work. Certainly, whatever those animals have is at least the evolutionary basis of our human notion of justice. But there is no evidence at all (thus far) that those sophisticated animals apply a notion like justice, or any other normative notion, to themselves, and then act on that. Yet it is precisely this self-application that is distinctive of human reasoning. ( $\mathrm{am}$ happy to be refuted in the future by new empirical evidence on this question.)

The truth is that $\mathrm{C} \& \mathrm{H}$ have unscientific reasons, indeed they have motivations, which make them want to believe that human beings and animals are not different in morally relevant respects. C\&H are advocates for animals and believe that in order to pursue this all claims to human uniqueness must be denied. But this seems to be because $\mathrm{C} \& \mathrm{H}$ share a claim with those 
they oppose: it is the very implausible claim that if human beings had some unique trait, then it would justify human beings treating animals cruelly. One wonders why anyone would believe that. $\mathrm{C} \& \mathrm{H}$ argue, in reverse: since we should not be cruel to animals, there are no significant differences. But this is not proper reasoning — it is a standard case of irrational wishful thinking.

\section{References}

Beckers, Tom \& De Houwer, Jan (2016) Reasoning Versus Association in Animal Cognition: Current Controversies and Possible Ways Forward. Journal of Comparative Psychology 130: 187-191.

Brosnan, S. \& de Waal, F. (2003). "Monkeys Reject Unequal Pay", Nature 425: 297-299.

Carlyle, T. (1833). SARTOR RESARTUS. Chapters V. to XI. Fraser's magazine, 8(48), 669-684.

Chapman, Colin A. \& Huffman, Michael A. (2018) Why do we want to think humans are different? Animal Sentience 23(1).

Korsgaard, C. (2006). "Morality and the Distinctiveness of Human Action", in Frans De Waal, Primates and Philosophers: How Morality Evolved, Princeton: Princeton University Press.

Korsgaard, C. (2018a). Fellow Creatures: Our Obligations to the Other Animals, Oxford: Oxford University Press.

Korsgaard, C. (2018b). "Rationality", in Critical terms for Animal Studies, edited by Lori Gruen, University of Chicago Press.

Marino, Lori \& Allen, Kristin (2017). The Psychology of Cows. Animal Behavior and Cognition 4: 474-498.

Marino, Lori \& Merskin, Debra (2019) Intelligence, complexity, and individuality in sheep. Animal Sentience 25(1)

Millikan, Ruth (1993) White Queen Psychology, Cambridge, Mass.: MIT Press.

Moti Nissani (2006) "Do Asian elephants (Elephas maximus) apply causal reasoning to tool-use tasks?", Journal of Experimental Psychology Animal Behavior Processes 32: 91-96.

Osler, W. (1891) Recent Advances in Medicine. Science 17: 170-171

Santos, Laurie \& Rosati, Alexandra (2015) The Evolutionary Roots of Human Decision Making. Annual Review of Psychology 66: 321-347. 